International Journal of Instruction e-ISSN: 1308-1470 • www.e-iji.net

Article submission code: 20201026225301

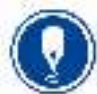

October $2021 \bullet$ Vol.14, No.4

p-ISSN: 1694-609X

pp. $965-980$

Received: 26/10/2020

Revision: 06/02/202
Accepted: 02/03/2021

OnlineFirst: 23/06/2021

\title{
Mindfulness as a Coping Strategy for EFL Learning in Education ${ }^{1}$
}

\section{Katherine Jane Skelly}

Madrid Open University, Spain, katherine_skelly@hotmail.com

\section{Jose Luis Estrada-Chichon}

Dr., University of Cadiz, Spain, joseluis.estrada@ uca.es

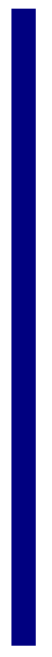

\begin{abstract}
Mindfulness is a relaxation technique that has been associated with positive effects when used as a coping strategy for stress and anxiety. In this regard, the objectives of this article are to investigate how mindfulness could help improve adolescents' ability to regulate their attention, emotion, behaviour and thinking; learn English as a Foreign Language (EFL); and increase EFL performance. A literature review of the previous research including 11 academic works published in scientific journals (2016-) using quantifiable data collection methods, statistical analysis software and having a control group as part of the investigation is important to be explored to find an answer to the following questions: Can mindfulness improve an adolescent's ability to regulate attention, emotion, behaviour and thinking? How can mindfulness improve Obligatory Secondary Education (OSE) students' ability to learn and acquire EFL? Can mindfulness increase working memory capacity and as a result increase students EFL performance? The findings from this literature review strongly suggest that mindfulness could be a highly effective strategy for improving the ability of OSE students in Spain to learn EFL, as a result of the reduced stress and anxiety levels experienced by adolescents when mindfulness is incorporated as part of a consistent daily routine.
\end{abstract}

Keywords: English as a Foreign Language, language instruction, mindfulness secondary education, stress, EFL

\section{INTRODUCTION}

Nowadays, adolescents are under significant pressure to do well in school. Two studies conducted by the World Health Organisation (WHO) $(2014 ; 2020)$ found that Spain ranked fourth as the country where adolescents felt the most pressured by schoolwork and homework. This is supported by the Organisation for Economic Co-operation and Development (OECD) (2015) that found that students in Spain had on average six and

\footnotetext{
${ }^{1}$ The current academic paper is the result of a Master's Degree dissertation presented at Madrid Open University (Spain, 2019-2020) by the author.

Citation: Skelly, K. J., \& Estrada-Chichon, J. L. (2021). Mindfulness as a Coping Strategy for EFL Learning in Education. International Journal of Instruction, 14(4), 965-980. https://doi.org/10.29333/iji.2021.14356a
} 
half hours of homework, compared to the world average weekly amount of the 72 countries that participated in study (no more than three hours). Moreover, the number of Spanish students who reported feeling certain levels of anxiety related to studying for exams was well above the average. This level of anxiety is one of the main reasons for students in Spain feeling dissatisfied with their life.

One potential solution could be mindfulness, a relaxation technique derived from Buddhism. The Mindfulness All- Party Parlimentary Group (MAPPG) (2015) argue that mindfulness "means paying attention to what is happening in the present moment in the mind, body and external environment, with an attitude of curiosity and kindness" (p. 4) This work will use this definition when referring to mindfulness as it is currently how the technique is defined and used as the basis for developing the teaching curriculum of mindfulness in primary and secondary schools in the British Education System. There is research (see Diaz-Gonzalez et al., 2018; Quach, Jastrowski, \& Alexander, 2016) to support findings that mindfulness is an effective technique in reducing stress and anxiety in adolescents, as well as improving their working memory capacity. Further research studies that suggest practising mindfulness could have a significant impact on improving the ability to learn and acquire English as a Foreign Language (EFL) (Fallah, 2016; Charoensukmongkol, 2019; Riggs \& Brown, 2017) of adolescents (Lueke \& Lueke, 2019; Mrazek, 2013; Sapthiang et al., 2019). Since statistics show that between 14.8$30 \%$ of Obligatory Secondary Education (OSE) students in Spain fail the subject of EFL every year (Chaparro, 2020), this issue needs to be addressed. Thus, this work will argue that mindfulness should be incorporated into Spanish secondary schools with time dedicated to the teaching and practice of mindfulness for OSE students in Spain, in order to try and significantly reduce the levels of stress and anxiety and therefore improve their EFL performance.

\section{Objectives}

1. To investigate if mindfulness can improve OSE student's ability to regulate their attention, emotion, behaviour, and thinking.

2. To explore how mindfulness can help to improve OSE students' ability to learn and acquire EFL.

3. To justify that mindfulness can increase EFL performance as a direct result of it increasing working memory capacity.

\section{Research Questions}

1. Can mindfulness improve an adolescent's ability to regulate attention, emotion, behaviour and thinking?

2. How can mindfulness improve OSE students' ability to learn and acquire EFL?

3. Can mindfulness increase working memory capacity and as a result increase students' EFL performance?

\section{METHOD}

The authors used search engines (Table 1) to identify sources of information. The criteria for the selected papers were searched by first using the key words and terminologies (Table 1). Furthermore, if there was a study of interest that had been referred to in another academic paper, the references were also used as a resource to 
find that study and it was then sourced directly using the search engines ${ }^{\mathrm{i}}$. Moreover, research studies were kept as recent as possible with the majority no later than 2016 . However, a few key studies that were prior to this date were also considered, including the data collected by the WHO, the OCED and Krashen (1982) -studies that were conducted before 2016 were excluded except for the few key studies mentioned in language research that are still relevant today-. All peer-reviewed works sourced have been published or cited in scientific journals describing original research and are considered quality research studies that could be replicated if necessary.

To be considered for inclusion in this research, the studies must have used quantifiable data collection methods, statistical analysis software to analyse their data and had a control group as part of their investigation. This was first judged by on the abstract, then all the research papers were read in more depth. In order to determine if research studies should be excluded, first the abstract was assessed, which quickly determined suitability regarding the method and findings. Also, if they had not been published in a scientific journal or used qualitative data collection methods then they were excluded because they could not be justified or replicated with statistical analysis. Mostly all of the studies that were conducted before 2016 were also excluded:

Table 1

Search engines: Database and descriptors

\begin{tabular}{|c|c|}
\hline Database & Search descriptors \\
\hline Proquest & "mindfulness"; "stress in teenagers"; "anxiety and EFL"; "mindfulness in adolescents" \\
\hline \multicolumn{2}{|c|}{ Wiley Online Library "mindfulness reducing stress"; "mindfulness reducing stress in teenagers" } \\
\hline Springer & "the effects of stress on the brain"; "adolescent brain development" \\
\hline Jstor & language performance" \\
\hline Medes & $\begin{array}{l}\text { "adolescentes y la salud mental"; "mindfulness y adolescentes en España"; "estrés y } \\
\text { ansiedad en adolescentes en España"; "el desarrollo de cerebro en adolescentes" }\end{array}$ \\
\hline Google Scholar & $\begin{array}{l}\text { "brain development in adolescents"; "English language anxiety and mindfulness"; } \\
\text { "mindfulness and EFL performance"; "the effects of mindfulness on the brain" }\end{array}$ \\
\hline
\end{tabular}

\section{FINDINGS}

Since this study needs to consider several aspects regarding answering the objectives, these will be separated into EFL learning and acquisition, stress and anxiety, and mindfulness. Table 2 below shows the number of studies that were assessed for selection to be included in this research:

Table 2

Academic papers selection

\begin{tabular}{lcl}
\hline Database & Academic papers reviewed & Academic papers selected \\
\hline Proquest & 10 & 3 \\
\hline Wiley Online Library & 15 & 5 \\
\hline Springer Link & 20 & 7 \\
\hline Jstor & 20 & 5 \\
\hline Medes & 10 & 2 \\
\hline Google Scholar & 30 & 12 \\
\hline
\end{tabular}

Table 3 outlines a summary of the research discussed and analysed including the topic, authors, scientific journal, the objectives of the study, the method, sample size and the results of the study: 
Table 3

Summary of the research

\begin{tabular}{|c|c|c|c|c|c|c|}
\hline Topic & Authors & $\begin{array}{l}\text { Scientific } \\
\text { Journal }\end{array}$ & Objectives & Method & Sample & Results \\
\hline $\begin{array}{l}\text { English } \\
\text { language } \\
\text { learning and } \\
\text { acquisition } \\
\end{array}$ & Krashen (1982) & & $\begin{array}{l}\text { To distinguish } \\
\text { between language } \\
\text { learning and } \\
\text { acquisition. }\end{array}$ & & & $\begin{array}{l}\text { Language acquisition } \\
\text { happens when we } \\
\text { understand what } \\
\text { people tell us. }\end{array}$ \\
\hline $\begin{array}{l}\text { The role of } \\
\text { mindfulness in } \\
\text { verbal learning } \\
\text { and memory }\end{array}$ & $\begin{array}{l}\text { Lueke and Lueke } \\
\text { (2019) }\end{array}$ & $\begin{array}{l}\text { Memory \& } \\
\text { Cognition }\end{array}$ & $\begin{array}{l}\text { To identify } \\
\text { mechanisms by } \\
\text { which mindfulness } \\
\text { can improve verbal } \\
\text { learning and } \\
\text { memory. }\end{array}$ & $\begin{array}{l}\text { Controlled stud } \\
\text { using the Rey } \\
\text { Auditory Verbal } \\
\text { Learning Test. }\end{array}$ & $\begin{array}{l}85 \\
\text { undergraduate } \\
\text { students }\end{array}$ & $\begin{array}{l}\text { They found a } \\
\text { significantly } \\
\text { enhanced encoding } \\
\text { process in the } \\
\text { mindfulness group. }\end{array}$ \\
\hline $\begin{array}{l}\text { The role of } \\
\text { mindfulness in } \\
\text { adolescent } \\
\text { stress and } \\
\text { well-being }\end{array}$ & $\begin{array}{l}\text { Erbe and Lohrmann } \\
\text { (2015) }\end{array}$ & $\begin{array}{l}\text { The Health } \\
\text { Educator }\end{array}$ & $\begin{array}{l}\text { To review the } \\
\text { literature regarding } \\
\text { mindfulness } \\
\text { programmes in } \\
\text { schools. }\end{array}$ & $\begin{array}{l}\text { A literature } \\
\text { review of } \\
\text { current research. }\end{array}$ & & $\begin{array}{l}\text { Mindfulness } \\
\text { positively affects } \\
\text { school performance. }\end{array}$ \\
\hline $\begin{array}{l}\text { Neural } \\
\text { underpinnings } \\
\text { in the role of } \\
\text { mindfulness in } \\
\text { emotion } \\
\text { regulation in } \\
\text { adolescents }\end{array}$ & Deng et al. (2020) & $\begin{array}{l}\text { Scientific } \\
\text { Reports }\end{array}$ & $\begin{array}{l}\text { To discover } \\
\text { neurological links } \\
\text { between mindfulness } \\
\text { and emotion } \\
\text { regulation. }\end{array}$ & $\begin{array}{l}\text { Experimental } \\
\text { study }\end{array}$ & $\begin{array}{l}43 \text { Chinese } \\
\text { adolescents }\end{array}$ & $\begin{array}{l}\text { Trait mindfulness } \\
\text { influence the } \\
\text { regulation of } \\
\text { negative emotions } \\
\text { and effects how they } \\
\text { are processed. }\end{array}$ \\
\hline $\begin{array}{l}\text { The role of } \\
\text { stress in } \\
\text { adolescents } \\
\text { causing } \\
\text { schizophrenia } \\
\end{array}$ & $\begin{array}{l}\text { Gomes and Grace } \\
(2017)\end{array}$ & $\begin{array}{l}\text { Schizophrenia } \\
\text { Bulletin }\end{array}$ & $\begin{array}{l}\text { To identify if } \\
\text { heightened stress } \\
\text { during adolescence } \\
\text { can lead to } \\
\text { schizophrenia. }\end{array}$ & $\begin{array}{l}\text { Follow-up } \\
\text { analysis from a } \\
\text { previous study } \\
\text { involving stress } \\
\text { induced rats. } \\
\end{array}$ & & $\begin{array}{l}\text { A predisposition to } \\
\text { stress hyper } \\
\text { sensitivity can lead } \\
\text { to schizophrenia. }\end{array}$ \\
\hline $\begin{array}{l}\text { The role of } \\
\text { mindfulness in } \\
\text { reducing } \\
\text { English } \\
\text { language } \\
\text { anxiety }\end{array}$ & $\begin{array}{l}\text { Chareonsukmongkol } \\
\text { (2019) }\end{array}$ & $\begin{array}{l}\text { International } \\
\text { Journal of } \\
\text { Bilingual } \\
\text { Education and } \\
\text { Bilingualism }\end{array}$ & $\begin{array}{l}\text { To investigate if } \\
\text { mindfulness had an } \\
\text { effect on the level of } \\
\text { anxiety experienced } \\
\text { when using EFL for } \\
\text { public speaking. }\end{array}$ & $\begin{array}{l}\text { Data collection } \\
\text { about } \\
\text { mindfulness and } \\
\text { presentation } \\
\text { scores. }\end{array}$ & $\begin{array}{l}333 \\
\text { undergradu-ate } \\
\text { students }\end{array}$ & $\begin{array}{l}\text { Low levels of } \\
\text { anxiety correlated } \\
\text { with high scores for } \\
\text { trait mindfulness. } \\
\text { Lower anxiety } \\
\text { correlated with } \\
\text { higher scores. }\end{array}$ \\
\hline $\begin{array}{l}\text { Stress affects } \\
\text { on the neural } \\
\text { assemble for } \\
\text { integrating } \\
\text { new } \\
\text { information } \\
\end{array}$ & Vogel et al. (2018) & $\begin{array}{l}\text { Learning and } \\
\text { Memory }\end{array}$ & $\begin{array}{l}\text { To investigate the } \\
\text { neural basis for } \\
\text { stress-induced } \\
\text { schema related } \\
\text { learning. }\end{array}$ & $\begin{array}{l}\text { Randomised } \\
\text { controlled study. }\end{array}$ & 55 participants & $\begin{array}{l}\text { Stress affected the } \\
\text { neural assemble } \\
\text { activated during } \\
\text { learning. }\end{array}$ \\
\hline $\begin{array}{l}\text { Mindfulness- } \\
\text { based stress } \\
\text { reduction in } \\
\text { adolescents }\end{array}$ & $\begin{array}{l}\text { Diaz-Gonzalez et al. } \\
\text { (2018) }\end{array}$ & Psicothea & $\begin{array}{l}\text { To assess the } \\
\text { potential effects of a } \\
\text { mindfulness } \\
\text { programme in } \\
\text { adolescent } \\
\text { stress levels. }\end{array}$ & $\begin{array}{l}\text { Randomised } \\
\text { clinical trial. }\end{array}$ & $\begin{array}{l}101 \\
\text { adolescents }\end{array}$ & $\begin{array}{l}\text { Statistically } \\
\text { significant decrease } \\
\text { in adolescent anxiety } \\
\text { levels. }\end{array}$ \\
\hline $\begin{array}{l}\text { The role of } \\
\text { mindfulness in } \\
\text { English } \\
\text { language } \\
\text { anxiety }\end{array}$ & Fallah (2016) & $\begin{array}{l}\text { An } \\
\text { International } \\
\text { Journal of } \\
\text { Experimental } \\
\text { Educational } \\
\text { Psychology } \\
\end{array}$ & $\begin{array}{l}\text { To investigate the } \\
\text { effect of mindfulness } \\
\text { on English language } \\
\text { anxiety. }\end{array}$ & Questionnaires & 295 & $\begin{array}{l}\text { Higher levels of } \\
\text { mindfulness were } \\
\text { associated with } \\
\text { lower EFL anxiety. }\end{array}$ \\
\hline $\begin{array}{l}\text { The role of } \\
\text { mindfulness } \\
\text { and cognitive } \\
\text { performance }\end{array}$ & Mrazek et al. (2013) & $\begin{array}{l}\text { Psychological } \\
\text { Science }\end{array}$ & $\begin{array}{l}\text { To see if } \\
\text { mindfulness could } \\
\text { decrease mind } \\
\text { wandering and } \\
\text { improve cognitive } \\
\text { performance. } \\
\end{array}$ & $\begin{array}{l}\text { Randomised } \\
\text { controlled } \\
\text { investigation. }\end{array}$ & $\begin{array}{l}48 \\
\text { Undergradua e } \\
\text { students. }\end{array}$ & $\begin{array}{l}\text { Mindfulness training } \\
\text { improved both GRE } \\
\text { Scores and working } \\
\text { memory capacity. }\end{array}$ \\
\hline $\begin{array}{l}\text { The role of } \\
\text { mindfulness } \\
\text { and changes in } \\
\text { the } \\
\text { hippocampus }\end{array}$ & Lardone et al. (2018) & $\begin{array}{l}\text { Neural } \\
\text { Plasticity }\end{array}$ & $\begin{array}{l}\text { To describe the } \\
\text { long-term effects of } \\
\text { meditation on brain } \\
\text { networks }\end{array}$ & $\begin{array}{l}\text { Controlled } \\
\text { study using } \\
\text { magnetoence } \\
\text { phalography in } \\
\text { Vipassana } \\
\end{array}$ & 60 participants & $\begin{array}{l}\text { Altered topography } \\
\text { in meditators, in } \\
\text { particular in the } \\
\text { frontal lobes. }\end{array}$ \\
\hline
\end{tabular}

International Journal of Instruction, October $2021 \bullet$ Vol.14, No.4 


\begin{tabular}{|c|c|c|c|c|c|}
\hline \multicolumn{6}{|c|}{ meditators } \\
\hline $\begin{array}{l}\text { The sub- } \\
\text { division of } \\
\text { ISLA }\end{array}$ & $\begin{array}{l}\text { Loewen and Sato } \\
\text { (2017) }\end{array}$ & & $\begin{array}{l}\text { To investigate the } \\
\text { ability to acquire } \\
\text { EFL in an ISLA } \\
\text { environment. }\end{array}$ & & $\begin{array}{l}\text { It is possible to } \\
\text { acquire EFL in an } \\
\text { ISLA environment, } \\
\text { considering several } \\
\text { factors. }\end{array}$ \\
\hline $\begin{array}{l}\text { The role of } \\
\text { mindfulness in } \\
\text { schools in } \\
\text { improving } \\
\text { mental health }\end{array}$ & $\begin{array}{l}\text { Sapthiang et al. } \\
\text { (2018) }\end{array}$ & $\begin{array}{l}\text { Journal of } \\
\text { Child and } \\
\text { Family } \\
\text { Studies }\end{array}$ & $\begin{array}{l}\text { To investigate the } \\
\text { impact of } \\
\text { mindfulness } \\
\text { programmes in } \\
\text { schools. }\end{array}$ & $\begin{array}{l}\text { A review of } \\
\text { previous } \\
\text { literature. }\end{array}$ & $\begin{array}{l}\text { Positive effects of } \\
\text { introducing a } \\
\text { mindfulness } \\
\text { programme in } \\
\text { schools. }\end{array}$ \\
\hline
\end{tabular}

\section{English Language Learning and Acquisition}

This article will take into consideration the distinctions between language learning and acquisition to see if there is evidence of the effects of stress only affecting learning, acquisition, or both. Krashen (1982) argues that language learning is a conscious process when individuals are aware of what it is they are learning. In contrast, he defines language acquisition as a subconscious process, where consequently people are not aware that they are actually acquiring the foreign language and while using it they are gradually developing the tactic language knowledge humans are preprogrammed in Chomskian terms. Krashen (1982) suggests that learning appears when learners need to make changes to the utterances after it has been learnt and consequently produced by the acquired system. Typically, during language acquisition, strategies that are used to learn native languages are employed to acquire the second language (L2). However, during language learning, it is argued that the learner uses other strategies, such as translation from their first language (Mirbazel \& Arjamndi, 2018).

Linguists have also been trying for years to establish the critical period to master second language (L2) acquisition and to find an answer for the optimal time to learn it (Rahmen et al., 2017). Although there is vast variation in the findings for age range of the critical period, Hartshorne, Tenenbaum, and Pinker (2018) found that the critical period (optimum age) for mastering syntax phenomena was much later than previous research has proposed. They suggest that the critical period for acquiring L2 syntax may be up to 17 years old. What is more of interest is that their research also revealed there was no difference between full immersion settings for L2 acquisition and those who had at least 30 years' experience of learning the L2. Furthermore, the results of this study imply that it is possible for OSE students to master EFL in a non-immersion setting such as the EFL classroom. Loewen and Sato (2017) have been investigating Instructed Second Language Acquisition (ISLA) and they argue that there are many contextual aspects to consider regarding ISLA in the EFL classroom. Their findings also correspond with the evolution of brain development during adolescence when neural plasticity and neurocircuitry is at its peak, particularly in the frontal lobe, which is involved with memory, language and problem-solving (Arain et al. 2013).

Neuroscience research has been investigating the neural underpinnings of the processes involved with language learning and acquisition. Some studies found evidence to suggest there are different mechanisms and pathways in the brain regarding the processes. Vogel et al. (2018) carried out a study using functional magnetic resonance imaging (fMRI) of neural activity. They found that when individuals are learning new 
information this is encoded by the hippocampus as new episodic memory, where a new schema (an associative network structure) in the brain is then created for this information. Nonetheless, there is considerable evidence to suggest that stress during adolescence can cause impairments in the ability to learn and acquire new information. Thus, they looked at schemas, which facilitate memory formation that could directly impact our ability to learn due to the effect on our mental scripts that have already been established. They argued that enhancing the effect of these schemas on our new learning is essential to improving education. In contrast, when people are acquiring information the medial prefrontal cortex is activated and finds a schema that has relevant prior knowledge, related to the information being acquired and then adds it to the already existing schema in our brains. Thus, if Krashens' (1982) definitions are accurate, and the research findings by Hartshorne et al. (2018), as well as taking into consideration the neuroplasticity of the brain during adolescence (Arain et al. 2013), one could argue that OSE students have the optimal conditions for learning and acquiring EFL.

Moreover, Krashen (1982) developed the Affective Filter Hypothesis that could explain the reason for such poor results in EFL by OSE students. He argues that humans have a filter, which decides how much intake can reach the Language Acquisition Device (LAD) proposed by Chomsky in the 1950s and 1960s, which everybody possesses and is an innate mental structure that processes the input and creates the schema in the longterm memories of the acquired knowledge. However, this filter can act as a barrier to language acquisition and Krashen (1982) contends that the barrier is up when the learner is unmotivated, lacking in confidence or experiences anxiety. The idea of an affective filter is also supported by recent neuroscience discoveries by Vogel et al. (2018) who investigated the effects of stress on the neural processes for integrating new information and prior knowledge. They found that individuals with higher levels of the stress hormone cortisol had pronounced connectivity in the hippocampus for schema related learning compared to the control group, who were not exposed to stressful circumstances. The findings revealed that during novel learning trials with new information and no prior knowledge, the mPFC showed enhanced connectivity, yet there was no enhanced connectivity found in the control group. This suggests that stressed individuals may experience difficulty in accessing and segregating the appropriate brain region for learning and acquisition.

\section{Stress and Anxiety in Learning English as Foreign Language}

According to Shonkoff and Garner (2020), stress and anxiety can cause detrimental effects to the developing brain during adolescence and can negatively affect their learning. They argue that those can lead to loss of neurons and neuronal connections in the hippocampus and $\mathrm{mPFC}$, which can result in increased anxiety, impaired memory, and therefore impaired learning. They contend that although the hippocampus can turn off the effects of cortisol, prolonged stress and anxiety reduces its capacity and as well as impairing memory also impedes neurogenesis in the hippocampus, which is essential for encoding new memories. In addition to the stress and anxiety caused by the overwhelming amount of homework, it is necessary to consider that OSE students may be experiencing anxiety in the EFL environment, which has been defined as "a distinct 
complex of self-perceptions, beliefs, feelings and behaviours related to classroom learning arising from the uniqueness of the language learning process" (Horwitz et al., 1986 , p. 128). Research has shown that this type of anxiety can also have negative consequences on students EFL results (Charoensukmongel, 2019) and thus increase the levels of anxiety and lack of confidence even more. These findings are in line with the previous research discussed and offer reasonable explanations as to why OSE students in Spain are experiencing such high levels of stress and anxiety and consequently are not learning the foreign language. Vogel and Schwabe (2016) argue that it is imperative that researchers consider the possible effects of stress in an educational setting and strategies to reduce it. However, they also note that stressful events do not always lead to a stressful response and that the response is very much dependent on the individual.

Although research studies cited have tried to control individual differences in learning EFL, it is not possible to control how individuals perceive stressful events. Past influences and preconditioned behavioural traits can determine whether one individual sees making an error in the EFL classroom as stressful or as feedback that they need to improve on next time. Furthermore, it can also be argued that individuals can acquire languages differently for similar reasons, for instance some individuals may have had prior experience from very young age to other languages that they are unaware of and as a result their brains may have already developed strategies that can actually be beneficial and improve their ability to acquire and learn languages (Kuhl, 2010). To counteract the strong negative effects of stress and anxiety coping strategies must be implemented by the stressed and anxious individual. Since the WHO's (2013, p. 6) action plan proposes that strategies are developed to overcome the issues discussed and it plans to help children develop "a positive sense of identity, the ability to manage thoughts, emotions, as well as to build social relationships, and the aptitude to learn and to acquire an education." In this regard, this article examines in detail how mindfulness could be used as a coping strategy to reduce adolescents' levels of stress and anxiety as well as fulfill the proposed criteria for the action plan of the WHO (2014).

\section{Mindfulness}

Kabat-Zinn (2003, p. 145) defines mindfulness as "the awareness that emerges through paying attention on purpose, in the present moment, and non-judgmentally to the unfolding of experience moment by moment." In this respect, the authors contend that mindfulness should be incorporated into the OSE curriculum in Spain either as a separate subject or as part of the physical education curriculum. There is quite a number of research to suggest that mindfulness may be beneficial to adolescents by reducing stress and anxiety levels, as well as improving executive functions in the brain including working memory (Riggs \& Brown, 2017). Deng et al. (2020) argue that for adolescents whose "higher brain regions" (p. 8), such as the mPFC, are still developing and are responsible for executive cognitive processes, mindfulness could help regulate the emotions, and reduce the effort and cognitive overload that they are prone to experience during this time of development. Their study revealed that higher levels of mindfulness in adolescents was correlated firstly, with lower reactions of emotion-generating brain regions and secondly, without activation of higher brain region. This could imply that if 
adolescents were aware and regularly practiced mindfulness, then not only could they benefit by having more emotionally stable behaviour, but their brains would also develop without the risk of damage that stress and anxiety can cause.

A meta-analysis review of mindfulness studies all of which involved adolescents by Erbe and Lohrmann (2015) showed that mindfulness consistently had significant results for its positive effects. Firstly, mindfulness could reduce depression and anxiety in adolescents, as well as stress, emotion regulation and general well-being. Moreover, the meta-analysis (Erbe \& Lohromann, 2015) found significant improvement to academic performance, which they argued is a result of mindfulness increasing attention and cognitive performance. In addition, a study by Diaz-Gonzalez et al. (2018) specifically tested the effects of mindfulness practice on Spanish adolescents aged 13-16 who were receiving psychological treatments as outpatients. They found that after eight weeks of practising mindfulness for 20 minutes with an instructor and a further 25 minutes at home there was a significant decrease in their reported levels of anxiety compared to the control group who received no treatment. As a result, other researchers have asked how it is possible that mindfulness could be responsible for improving academic performance and reducing levels of stress and anxiety.

Although the exact neural pathways that mindfulness affects are still unknown, several studies have found that long-term practice of mindfulness can cause increased volume the hippocampus (Lardone et al. 2018; Greeneberg et al. 2019). Lardone et al. (2018) revealed by using metaencephalography that participants who had been practising mindfulness every day for a year had better neural connections in their brains between the right hippocampus and the rest of the network. So, the right hippocampus is involved with the creation of future events or prospective memories, including novel memory without prior knowledge or a schema that is already present. However, they also found that the left hippocampus was activated when information regarding past events was registered. Thus, their findings support the idea on a neurological level that there is a difference between learning new information and acquiring information if it is already connected to a schema that has been established in the brain. Moreover, it provides evidence that mindfulness can increase working memory capacity. In contrast, Greeneberg et al. (2019) carried out an investigation to reveal the results after only practising mindfulness for four weeks. There were no significant differences between the control group and the mindfulness group regarding the right hippocampus. Nevertheless, they did find a significant increase in the volume of the left hippocampus in the mindfulness group after only this short time of practising mindfulness. This suggests that even for those who have only just started consistently practising mindfulness there are almost immediate benefits. As this work has already shown that the left hippocampus is essential to working memory capacity, these findings provide further evidence that mindfulness can indeed increase EFL performance.

Considering that this research is focusing on adolescents, it is important to mention that the research findings by Lardone et al. (2018) and Greeneberg et al. (2019) were done with participants aged 18-50. However, a research study by Quach, Jastrowski, and Alexander (2016) also carried out a four-week study of the effects of practising 
mindfulness on directly working memory capacity, but specifically in adolescents aged 12-17. The findings revealed that after four weeks of practising mindfulness, their working memory capacity test scores increased compared to the control group. Although they did not use technology to assess differences in brain regions, the memory tests used clearly suggest that mindfulness can improve working memory capacity. Furthermore, there is also evidence to show that regularly practising mindfulness can reduce the stress and foreign language anxiety in an EFL setting. Charoensukmongkol (2019) contends that the anxiety experienced by EFL speakers when using the language in all skill sets can hinder their performance. His study focused using EFL for public speaking when giving a presentation. He compared students test scores for state and trait mindfulness and found that students who reported feeling high levels of state and trait mindfulness, also claimed to feel less anxious during presentations using EFL. Moreover, the high levels of state and trait mindfulness reported in students was found to predict higher scores on presentations given in EFL than those students who reported feeling anxious or low levels of state and trait mindfulness.

Fallah (2016) carried out a similar research study regarding the impact of mindfulness on English language anxiety and found that higher levels of mindfulness correlated strongly with less English language anxiety. Moreover, once again higher levels mindfulness and self-awareness were able to predict levels of anxiety and EFL performance. Given that statistics in Spain reported that $67 \%$ of OSE students felt anxious (OECD, 2015) it is not surprising that so many have problems passing EFL subject (Meyer, 2018). Even though the mechanisms by which mindfulness can improve anxiety and stress are unknown, some research has suggested that it also links to the effects stress and anxiety can have on learning and memory (Vogel \& Schwabe, 2016). They argue that being stressed may lead to stronger memories of negative events such as failing exams or being embarrassed. These memories then lead to negative stressful emotions, which are context dependent in the classroom and due to the mere fact of being at school the students feel constantly stress. They contend that this level of stress is detrimental to the formation of new memories and memory retrieval.

A research investigation by Mrazek, Franklin, Phillips, Baird, and Schooler (2013) found surprising results when they introduced mindfulness into a university class for 1020 minutes a day for two weeks, as well as ten minutes outside of class. The researchers used a modified version of the Graduate Record Education (GRE) test, which is used for admission into graduate school in the United State and Canada. The participants were given four 45-minute classes a week for two weeks with clear instructions about how to incorporate and practise mindfulness in their daily lives. The students completed the modified GRE test, which included a verbal test using vocabulary and an element of reading comprehension before and after introducing mindfulness. The researchers choose to exclude accuracy rates on the test of less than $85 \%$ from the results. After only two weeks of practising mindfulness the participants' vocabulary test and reading comprehension scores increased on average by $30 \%$.

A recent study by Lueke and Lueke (2019) also investigated the effects of mindfulness on verbal memory and learning. They argued that mindfulness increases working 
memory capacity through improving levels of encoding. They also gave participants a two-week course of mindfulness and used a control with no mindfulness knowledge or training. Their findings supported their hypothesis that mindfulness does increasing encoding, and thus, they contend that it is through this mechanism that mindfulness can improve test scores. These findings also support the neurological evidence previously discussed (Greeneberg et al. 2019) because they found evidence to suggest that only after two weeks, mindfulness could increase the capacity to learn new information, which would be processed by the left hippocampus using working memory.

Regarding the implications for L2 learning, Ullmann and Lovelett (2018) agree that the hippocampus initiates the learning and consolidation of new information, whereas the prefrontal cortex is responsible for recalling previously stored information. They argue that declarative memory prompted by the hippocampus concerns learning facts and explicit knowledge such as grammar, and is more active during childhood, however, it starts to plateau during adolescence. Thus, mindfulness could potentially increase the ability of declarative memory, since research has already shown that it can increase hippocampus volume in adolescents. Further evidence to support that claim that mindfulness can improve EFL results can be found in an investigation by Strickland and Selwyn (2019). They introduced mindfulness to undergraduate participants for two weeks using only a three-minute guided video of mindfulness. They tested error rates of students using a Single Letter Cancellation Test before and after the two-week period. They found that after the two-week period students in the mindfulness group made significantly fewer errors on the test than the control group.

Moreover, Franco, Mañas, Cangas, and Gallego (2011) studied a group of first year compulsory secondary school students in Spain to measure the students' levels of selfconcept and anxiety levels they used questionnaires both pre-test and post-test. The experimental group were given a 1 hour 30-minute mindfulness training per week and instructed to practise mindfulness at home for 30 minutes daily based on the training they received for a period of ten weeks. They analysed differences between the control group for: Total academic performance, Spanish language and literature, foreign language, self-concept, state, and trait anxiety. They found statistically significant differences between all the groups for all the variables analysed after the post-test, despite the fact there were no differences between any of the variables for the groups pre-test. What is more, the variable with the largest improvement was academic performance, although all the variable saw large to very large improvements. In a similar study conducted in a Chilean secondary school with adolescents aged between 12 and 14 years, Langer, Schmidt, Aguilar-Parra, Cid, and Magni (2017) found significant reductions in stress and anxiety levels after introducing the experimental group to eight weekly sessions mindfulness for 45 minutes each session. Despite they did not measure differences in academic performance, this supports the previous research that has also found mindfulness can reduce stress and anxiety in teenagers.

\section{DISCUSSION}

In terms of research objectives and questions, the findings from this study support the idea that mindfulness can increase EFL performance in OSE students, as well as reduce 
the high levels of stress and anxiety. First, although there have only been limited research studies conducted regarding the ability of mindfulness to regulate emotions in adolescents, the results are promising (Erbe \& Lohrmann, 2015; Deng et al., 2020). If the regular practice of mindfulness is responsible for regulating emotion in adolescents, this could potentially have a significant positive impact on the lives of OSE students. Furthermore, since Deng et al. (2020) found that because of emotion regulation, cognitive overload was also reduced and consequently the higher brain regions responsible for executive cognitive processes in adolescents are not activated unnecessarily. This discovery is also of great importance because such cognitive overload in these regions during adolescence has been correlated with developing mental health disorders, such as schizophrenia as adults (Gomes \& Grace, 2017).

Second, despite the lack of evidence to support the idea that emotional regulation due to mindfulness practice can increase EFL performance, there is ample evidence to suggest how mindfulness could be contributing to increased EFL performance in particular (Chareonsukmongkol, 2019; Vogel et al. 2018; González-Díaz et al. 2018). The findings strongly suggest that there is a clear link between regularly and consistently practising mindfulness every day with reduced levels of stress and anxiety. It could be argued that the mere fact of reducing stressing and anxiety in adolescents is what is responsible for improved EFL performance in class, learning and acquisition. The research by Fallah (2016) found a direct correlation between practising mindfulness in young adults with significantly reduced reported levels of anxiety when having to use EFL in the classroom. This was supported by Charoensukmongkol (2019) who found a strong correlation between practising mindfulness and reduced language anxiety.

The idea that a significant reduction in stress and anxiety could improve EFL performance is very plausible if Krashen's (1982) affective filter hypothesis is considered. Krashen (1982) argued that language learners have a filter that decides if the input they receive will be passed onto what Chomsky referred to as the LAD or not. He contended that this filter is more receptive to input when the EFL learner is in an emotionally balanced state with positive thoughts. However, when the EFL learner is experiencing negative emotions such as frustration, stress, or anxiety the filter is up and blocks the acquisition of comprehensible input for the learner. The consequences of these findings for EFL learners are imperative to improving the secondary education system in Spain and the EFL performance of OSE students. Thus, this study argues that the negative emotions experienced by a vast majority of OSE students is the primary cause for the lack of EFL performance at secondary school.

Third, the research discussed has shown strong evidence to support the notion that mindfulness can increase EFL test scores and performance results at school (Mzarek et al. 2013; Lueke \& Lueke, 2019) due to the reduction in stress and anxiety levels. There is also research with statistically significant findings cited that suggest mindfulness increases working memory capacity, and as a direct result this could be responsible for the increased EFL academic performance. The findings from this study strongly indicate that regularly practising mindfulness has the potential to increase the volume of the hippocampus (Lardone et al. 2018; Greeneberg et al. 2019). As the hippocampus is 
involved with working memory capacity, in particular the left hippocampus, these findings indicate that mindfulness can improve OSE students' ability to learn EFL at school. It is generally agreed upon that there is a distinction between learning and acquisition. The neurological evidence discussed indicates that this concept is supported with distinct pathways in the brain for learning and acquiring information.

The authors of this work contend that since the research studied here indicates that new information is learnt via the hippocampus and acquired information is processed through the mPFC (Vogel et al., 2018), that if mindfulness were to be incorporated into the Spanish secondary curriculum, both EFL learning and acquisition results would be increased. This can be explained by the findings from the research cited, which have shown that not only does mindfulness directly increase working memory capacity in the hippocampus, but it can also reduce the stress and cognitive overload experienced by the developing prefrontal cortex during adolescence. Thus, if the prefrontal cortex were functioning at its optimum capacity because of mindfulness practice, OSE EFL students may be capable of unconsciously acquiring EFL in the classroom.

There is new research investigating the idea of ISLA (Loewen \& Sato, 2017), which refers to the concept of students acquiring EFL through instructed teaching in the EFL classroom. This idea arose based on the individual differences seen in learners and their performance. The research examined here may lead to plausible explanation as to why some individuals learn EFL better than others. Firstly, this study has shown that EFL learners who score highly for state and trait mindfulness characteristics indicate statistically significant trends for scoring highly on tests and oral presentations, these characteristics were present in the participants' personality and self-awareness without even integrated the practice of mindfulness (Charoensukmongkol, 2019). Thus, this work argues that such personality characteristics could account for the individual differences observed in EFL learners and suggests that those with more of mindful traits in their personality are able to acquire EFL through ISLA compared to EFL learners.

It is important to note that some of the studies only implemented mindfulness for as little as ten minutes a day for two weeks (Mrazek et al. 2013) found statistically significant results for improved vocabulary test scores with an average improvement of $30 \%$. In fact, even research that introduced a three minute of guided mindfulness video daily found statistically significant results to suggest that it can improve EFL performance in OSE students. Therefore, the authors want to recommend that the Spanish education system seriously consider implementing mindfulness as a technique for OSE student to learn to self-cope with their state of mind and improve adolescent mental health. Sapthiang, Gordon, and Shonin (2019) recommend that the practice introduced should be an approach to mindfulness that has already been empirically validated such as learning to breathe (Erbe \& Lohrmann, 2015). The benefits discussed in both the long and short term to adolescents considerably outweigh and short-term interruption that would be experienced from its implementation. 


\section{CONCLUSION}

Mindfulness clearly plays an important role in reducing the levels of stress and anxiety experienced by OSE students on a general basis, as well as more specifically in an EFL context. Firstly, this study has shown that there are serious mental health issues for teenagers in OSE that need to be addressed immediately. As well as the impact these high levels of stress and anxiety are having on their potential to learn new input. Additionally, this research has identified that there are specific neural pathways, which are activated in the process of learning and acquiring information, showing that under stressful conditions these pathways are negatively impacted with the brain struggling to acquire and consolidate the information being learnt. The research discussed suggests that mindfulness can help reduce stress and anxiety not only on a general basis for adolescents, but also reducing language specific anxiety, which as a result has been shown to result in improved EFL performance.

\section{REFERENCES}

Arain, M., Haque, M., Johal, L., Mathur, P., Nel, W., Rais, A., Sandhu, R., \& Sharma, S. (2013). Maturation of the adolescent brain. Neuropsychiatric disease and treatment, 9, 449-461. doi: 10.2147/NDT.S39776

Chaparro, L. (January 13, 2020). El 40\% de los alumnos de tercero de Secundaria suspenden Matemáticas. El Diario de Córdoba https://www.eldiadecordoba.es/cordoba/alumnos-terceroSecundaria-suspenden-

Matematicas_0_1423657730.html

Charoensukmongkol, P. (2019). The role of mindfulness in reducing English language anxiety among Thai college students. International Journal of Bilingual Education and Bilingualism, 22(4), 414-427. doi: 10.1080/13670050.2016.1264359

Deng, X., Gao, Q., Zhang. L., \& Li, Y. (2020) Neural underpinnings of the role of trait mindfulness in emotion regulation in adolescents. Mindfulness, 11, 1120-1130. doi: 10.1007/s12671-019-01276-7

Deng, X., Sang, B., Ku, Y., \& Sai, L. (2019). Age-related differences in the late positive potential during emotion regulation between adolescents and adults. Scientific Reports: 9/5738. doi: 10.1038/s41598-019-42139-4

Erbe, R., Lohrmann, D. (2015, Fall). Mindful meditation for adolescent stress and wellbeing: A systematic review of literature with implications for school health programs. Health Educator, 47(2), 12-19.

Fallah, N. (2019). Mindfulness, coping self-efficacy and foreign language anxiety: A mediation analysis. An International Journal of Experimental Educational Psychology, 37(6), 745-756. doi: 10.1080/01443410.2016.1149549

Franco, C., Mañas, I., Cangas, J. A., \& Gallego, J. (2011). Exploring the effects of a mindfulness program for students of secondary school. International Journal of Knowledge Society Research, 2(1), 14-28. doi: 10.4018/jksr.2011010102 
Gilboa, A., \& Marlatte, H. (2017). Neurobiology of schemas and schema-mediated memory. Trends in Cognitive Science, 21(8), 618-631. doi: 10.1016/j.tics.2017.04.013

Gomes, V. F., \& Grace, A. A. (2017). Adolescent stress as a driving factor for schizophrenia development-A basic science perspective. Schizophrenia Bulletin, 43(3), 486-489. doi: 10.1093/schbul/sbx033

Gonzalez-Diaz, M.C., Perez-Dueñas, C., Sanchez-Raya, A., Moriana-Elvira, J. A., \& Sánchez-Vázquez, V. (2018). Mindfulness-based stress reduction in adolescents with mental disorders: A randomised clinical trial. Psicothea, 30(2), 165-170. doi: 10.1016/j.clysa.2016.09.002

Greenberg, J., Romero, V.L., Elkin-Frankston, S., Bezdek, A.M., Schumacher, H.E., \& Lazar, W.S. (2019). Reduced interference in working memory following mindfulness training is associated with increases in hippocampal volume. Brain, Imaging and Behavior, 13, 366-376. doi: 10.1007/s11682-018-9858-4.

Hartshorne, J.K., Tenenbaum, J.B., \& Pinker, S. (2018). A critical period for second language acquisition: Evidence from 2/3 million English speakers. Cognition, 177, 263277. doi: 10.1016/j.cognition.2018.04.007

Horwitz, E., Horwitz, M., \& Cope, J. (1986). Foreign language classroom anxiety. The Modern Language Journal, 70(2), 125-132. doi: 10.2307/327317

Kabat-Zinn, J. (2003). Mindfulness-based interventions in context: Past, present, and future. Clinical Psychology: Science and Practice, 10, 144-156. doi: 10.1093/clipsy/bpg016

Krashen, D. S. (1982). Principles and Practice in Second Language Acquisition. Oxford, UK: Pergamon Press.

Kuhl, K. P. (2010). Brain mechanisms in early language acquisition. Neuron, 67(5),713727. doi: 10.1016/j.neuron.2010.08.038

Langer, I.A., Schmidt, C., Aguilar-Parra, M.J., Cid, C., \& Magni, A. (2017). Mindfulness y la promoción de la salud mental en adolescentes: efectos de una intervención en el contexto educativo. Revista Médica de Chile, 145, 476-482. doi: $10.4067 /$ S0034-98872017000400008

Lardone, A., Liparoti, M., Sorrentino, P., Rucco. R., Jacini, F., Polverino, A., Minino, R., Poseli, M., Baselice, F., Sorriso, A., Ferraioli, G., Sorrentino, G., \& Mandolesi, L. (2018). Mindfulness meditation is related to long-lasting changes in hippocampal functional topology during resting state: A magnetoencephalography study. Neural Plasticity, 1-10. doi: 10.1155/2018/5340717

Loewen, S. \& Sato, M. (2019). Instructed Second Language Acquisition and English language teaching: Theory, research, and pedagogy. In X. Gao (ed.), Second Handbook of English Language Teaching (1131-1148). Springer International Handbooks of Education. 
Lueke, A., \& Lueke, N. (2019). Mindfulness improves verbal learning and memory through enhanced encoding. Memory \& Cognition, 47, 1531-1545. doi: 10.3758/s13421-019-00947-z

MAPPG (2015). Mindful Nation UK: Report by the Mindfulness All-Party Parliamentary Group (MAPPG). https://mindfulnessinschools.org/wpcontent/uploads/2017/09/Mindfulness-APPG-Report_Mindful-Nation-UK_Oct20151.pdf

Meyer, L. (January 30, 2018). La meditación se cuela en los colegios. Ethic. https://ethic.es/2018/01/meditacion-se-cuela-en-colegios/

Mirbazel, K.S., \& Arjmandi, M. (2018). The effect of English teachers' code-switching and translation strategies on the enhancement of Iranian EFL junior secondary program students' language. Learning. Journal of Applied Linguistics and Language Research, 5(3), 204-217.

Mrazek, D. M., Franklin, S.M., Phillips, D.T., Baird, B., \& Schooler, W. J. (2013). Mindfulness training improves working memory capacity and GRE performance while reducing mind wandering. Psychological Science, 24(5), 776-781. doi: $10.1177 / 0956797612459659$

OECD (2015). PISA results in focus. https://www.oecd.org/pisa/pisa-2015-results-infocus.pdf

Quach, D., Jastroski, E.K., \& Alexander, K. (2016). A randomized controlled trial examining the effect of mindfulness medition on working memory capacity in adolescents. Journal of Adolescent Health, 58, 489-496. doi: 10.1016/j.jadohealth.2015.09.024

Rahman, M.M., Islam, M.S., Karim, A. (2019). English Language Teaching in Bangladesh Today: Issues, Outcomes and Implications. Language Test Asia, 9(9). doi: 10.1186/s40468-019-0085-8

Riggs, N.R., \& Brown, S.M. (2017). Prospective associations between peer victimization and dispositional mindfulness in early adolescence. Prevention Science, 18, 481-489. doi: 10.1007/s11121-017-0750-z

Sapthiang, S., Van Gordon, W., \& Shonin, E. (2019). Health school-based mindfulness interventions for improving mental health: A systematic review and thematic synthesis of qualitative studies. Journal of Child and Family Studies, 28, 2650-2658. doi: 10.1007/s10826-019-01482-w

Shonkoff, P.J., \& Garner, S.A. (2012). The lifelong effects of early childhood adversity and toxic stress. Pediatrics, 129(1), 232-246. doi: 10.1542/peds.2011-2663

Strickland, K., \& Sewlyn, J. (2019). Effects of a short mindfulness meditation on cognitive function. Sentience, 18, 1-4. doi: 10.1080/10615806.2019.1596672 
Ullman, T.M., \& Lovelett, T.J. (2018). Implications for the declarative procedural model in second language learning: The role of memory enhancement techniques. Second Language Research, 34(1), 39-65. doi: 10.1177/0267658316675195

Vogel, S., Kluen, M.L., Fernández, G., \& Schwabe, L. (2017). Stress leads to aberrant hippocampal involvement when processing schema-related information. Learning and Memory, 25, 21-30. doi: 10.1101/lm.046003.117

Vogel, S., Kluen, M.L., Fernández, G., \& Schwabe, L. (2018). Stress affects the neural ensemble for integrating new information and prior knowledge. NeuroImage, 173, 176187. doi: 10.1016/j.neuroimage.2018.02.038

Vogel, S., \& Schwabe, L. (2016). Learning and memory under stress: Implications for the classroom. Science of Learning, 1(16011), 1-10. doi: 10.1038/npjscilearn.2016.11

WHO (2013). Mental Health Action Plan 2013-2020. https://apps.who.int/iris/bitstream/handle/10665/89966/9789241506021_eng.pdf;jsessio $\mathrm{n} \% 20 \mathrm{id}=23470431$ A5B5FFABC7ACEB7DB6564699? sequence $=1 /$

WHO (2014). Health for the world's adolescents: A second chance in a second decade. https://apps.who.int/adolescent/second-

decade/files/1612_MNCAH_HWA_Executive_Summary.pdf

WHO (2020). Spotlight on adolescent health and well-being. https://apps.who.int/iris/bitstream/handle/10665/332091/9789289055000-eng.pdf

in Deng et al. (2020) the references were used to find the title and journal source for studies cited in the paper from Deng, Sang, Ku, and Sai (2019) as well as Riggs and Brown (2017). In addition to Vogel et al. (2018), which cited the articles by Gilboa and Marlatte (2017) as well as Vogel et al. (2017) and Lueke and Lueke (2018). 